\title{
Martins, Moisés de Lemos; Sousa, Helena; Cabecinhas, Rosa (eds.) (2006) Comunicação e Lusofonia - Para uma abordagem crítica da cultura e dos media, Porto: Campo das Letras.
}

Daniela Bertocchi*

Como definimos lusofonia num mundo globalizado? De que maneira configuramos hoje a identidade lusófona? Que (auto-)imagem fazemos da comunidade de duzentos milhões de falantes da Língua Portuguesa? Como percebemos a produção, a distribuição e a recepção de mensagens mediáticas no espaço multicontinental de uma mesma língua? Que estereótipos identificamos neste processo? Que significa viver e partilhar uma mesma língua em oito países diferentes?

Essas são interrogações que correm o sério risco de cair naquilo que a pesquisadora Maria Manuel Baptista chamou de "buraco negro" da lusofonia. Tendem a ser arrastadas para o espaço da "não-reflexão" a respeito daquilo que une todos os falantes da língua portuguesa. Ocorre que o debate em torno do que seja a lusofonia desde há muito tempo vem sendo assinalado - pelo menos no contexto da cultura portuguesa, segundo a especialista - como um lugar do "não-conhecimento" e, sobretudo, do "não-reconhecimento" (mesmo a despeito de o termo ser amplamente utilizado). O que falta são estudos e análises críticas, em qualidade e quantidade, que dêem conta da produção de "uma narrativa já não dominada pela ideologia imperial”.

É exatamente na contra-mão da inércia rumo ao debate menos espesso e comum que surge a brava tentativa de iluminar o conceito de lusofonia e correlacioná-lo com o campo da comunicação, abrindo, a partir daí, um ambiente propício à discussão atualizada sobre a presença desta noção nos vários cantos do mundo em que se fala a Língua Portuguesa. Esta é a proposta da obra coletiva Comunicação e Lusofonia - Para uma abordagem crítica da cultura e dos media, publicada no final de 2006 pelo Centro de Estudos de Comunicação e Sociedade da Universidade do Minho. Os textos apresentados na coletânea são resultado de trabalhos levados a cabo durante a I Conferência Internacional sobre Comunicação e Lusofonia realizada em Outubro de 2005 pela Universidade do Minho em articulação com o projeto Lusocom: Estudos das Políticas de Comunicação e Discursos no Espaço Lusófono. A obra traz artigos de quinze pesquisadores vinculados a centros de pesquisas de Angola, Brasil, Portugal, Timor-Leste, Moçambique e Estados Unidos da América.

A discussão proposta pela obra não se circunscreve somente em torno de uma caracterização da comunidade lusófona. Assume a lusofonia como uma "construção

\footnotetext{
* Doutoranda e investigadora no Centro de Estudos e Comunicação da Universidade do Minho (danielabertocchi@
} gmail.com). 
extraordinariamente difícil” e um campo que integra instituições com objetivos muitas vezes conflituosos, difusos e contraditórios.

$\mathrm{Na}$ primeira parte do livro, o leitor encontra quatro artigos que tanto problematizam a lusofonia enquanto discurso e "cosa mentale" como interrogam o papel da comunicação e dos media neste âmbito. Nesse momento inicial, as pesquisadoras brasileiras Regina Helena Pires de Brito e Neusa Maria Oliveira Barbosa Bastos chamam a atenção para o fato de que a idéia de lusofonia não é una nem coesa nos países de expressão oficial portuguesa. Apontam, além disso, que fora do território português o problema etimológico e semântico do próprio termo "lusofonia" - de Lusitânia, lusu: designações que remetem a lusitano, português, Portugal - causa, por vezes, desconforto, posto que remete, sem muita dúvida, à centralidade da matriz portuguesa. Aqui também encontram-se as reflexões do antropólogo Luís Cunha, o qual analisa o modo como alguns textos literários portugueses e brasileiros de referência (como Macunaíma e Jangada de Pedra) propõem e projetam “etnopaisagens”; do catedrático Moisés de Lemos Martins, a sugerir a possibilidade de os países lusófonos fazerem uma leitura afirmativa e prospectiva de sua presença no mundo; e da já citada Maria Manuel Baptista, que realiza uma espécie de arqueologia do conceito de lusofonia.

A segunda parte da obra apresenta cinco textos que procuram aferir a relevância das políticas da língua no contexto do desenvolvimento de uma área cultural e comunicacional no atual mundo globalizado. Sobre esta perspectiva, são apresentados os artigos de José Carlos Venâncio a respeito da legitimidade e identidade das literaturas africanas em língua portuguesa; do jornalista Joaquim Paulo da Conceição, sobre o percurso tomado por Angola na valorização das línguas portuguesa e angolana; de Eduardo Namburete, que discute a relevância de uma política lingüística para Moçambique; e de Barbosa Bastos e Pires de Brito, esta última assinando um artigo com Benjamin de Araújo Corte-Real sobre o papel da língua portuguesa como elemento indispensável para recuperar e preservar a identidade histórica, cultural e política dos timorenses.

São também consideradas na coletânea - na terceira e última parte, esta com seis artigos - as principais estruturas de comunicação, nacionais e supranacionais, do espaço lusófono, e ainda a questão dos estereótipos sociais veiculados pelos media. O leitor depara-se aqui com textos de pesquisadores brasileiros e portugueses como Maria Immacolata Vassallo de Lopes, Benalva da Silva Vitorio, Helena Sousa, Rosa Cabecinhas, César Bolaño e Joseph Straubhaar, que destacam, cada um dentro de seu domínio de estudo, a narrativa ficcional de televisão brasileira como valor estratégico na criação e consolidação de novas identidades culturais partilhadas; o papel que é atribuído aos canais internacionais da televisão portuguesa (RTP Internacional e RTP África) na reconfiguração da cultura lusófona; a centralidade que exerce a Rede Globo de televisão no mercado brasileiro; a sobreposição de identidades locais, regionais e supranacionais com base nas "regiões" lingüístico-culturais; e, por fim, como jovens portugueses e timorenses percebem a história da humanidade e de seus respetivos países. 
Pela abrangência, atualidade e maturidade discursivas, Comunicação e Lusofonia já nasce como obra de leitura obrigatória para todos aqueles que buscam perceber de que forma o espaço lusófono alberga realidades completamente distintas uma das outras, manifestando-se como universo de desigualdades sociais, econômicas, culturais, demográficas. Seu mérito está sensivelmente na coragem em refutar o "não-dito", desvelando, sempre sob o olhar de pesquisadores atentos, a complexidade da vivência e partilha de uma mesma língua em oito diferentes países nos tempos atuais. 